\title{
Neuropharmacological effects of Phoneutria nigriventer venom on astrocytes
}

\author{
Catarina Rapôso ${ }^{\text {a, } 1}$, Ulrika Björklund ${ }^{b}$, Evanguedes Kalapothakis ${ }^{c}$, Björn Biber ${ }^{\text {d }}$, \\ Maria Alice da Cruz-Höfling ${ }^{\text {a }}$, Elisabeth Hansson ${ }^{\text {b, * }}$ \\ a Department of Biochemistry and Tissue Biology, Institute of Biology, State University of Campinas (UNICAMP), 13 083-970 Campinas, SP, Brazil \\ ${ }^{\mathrm{b}}$ Department of Clinical Neuroscience, Institute of Neuroscience and Physiology, The Sahlgrenska Academy, University of Gothenburg, SE 41345 \\ Gothenburg, Sweden \\ ${ }^{c}$ Department of General Biology, Institute of Biological Sciences, Federal University of Minas Gerais (UFMG), $31270-901$ Belo Horizonte, MG, Brazil \\ ${ }^{\mathrm{d}}$ Department of Anaesthesiology and Intensive Care Medicine, Institute of Clinical Sciences, The Sahlgrenska Academy, University of Gothenburg, SE 41345 , \\ Gothenburg, Sweden
}

\section{A R T I C L E I N F O}

\section{Article history:}

Received 22 February 2016

Received in revised form

7 April 2016

Accepted 14 April 2016

Available online 16 April 2016

\section{Keywords:}

Arthropod venom

Astrocytes

$\mathrm{Ca}^{2+}$ responses

Stress fibers

TLR4

Glutamate

\begin{abstract}
A B S T R A C T
Bites from genus Phoneutria (Ctenidae, Araneomorpha) are the second most frequent source of spider accidents in Southeast Brazil. Severe envenoming from Phoneutria nigriventer produces vision disturbance, tremor and convulsion, suggesting that the CNS is involved; however, the mechanisms by which $P$. nigriventer venom (PNV) affects the CNS remain poorly understood. The present study aimed to investigate whether PNV directly impairs astrocytes. Cultured astrocytes were exposed to PNV, and intracellular $\mathrm{Ca}^{2+}$ release and signaling were measured (Fura-2/AM), $\mathrm{Na}^{+} / \mathrm{K}^{+}$-ATPase and Toll-like receptor 4 (TLR4) involvement were investigated, actin filaments were stained (Alexa ${ }^{\mathrm{TM}} 488$-conjugated phalloidin probe), the G-actin/F-actin ratio was determined, and the expression level of connexin 43 ( $\mathrm{Cx} 43$ ) was assessed. Incubation in $\mathrm{Ca}^{2+}$-free buffer did not change the $\mathrm{Ca}^{2+}$ responses. However, preincubation in thapsigargin/caffeine completely abolished these responses, suggesting that PNV-evoked $\mathrm{Ca}^{2+}$ transients were from intracellular $\mathrm{Ca}^{2+}$ stores. Pretreatment with a $\mathrm{Na}^{+} / \mathrm{K}^{+}$-ATPase antagonist (ouabain) or a TLR4 antagonist (LPS-RS) decreased or increased the $\mathrm{Ca}^{2+}$-evoked transients, respectively. Astrocytes showed altered actin filament structure after PNV exposure. PNV treatment increased the expression levels of $\mathrm{Na}^{+} / \mathrm{K}^{+}$-ATPase and $\mathrm{Cx} 43$ but decreased those of TLR4. The present results suggest that PNV directly affects astrocytes. $\mathrm{Na}^{+} / \mathrm{K}^{+}$-ATPase may thus represent a more specific drug target for controlling the neurotoxicity of PNV.
\end{abstract}

๑) 2016 Elsevier Ltd. All rights reserved.

\section{Introduction}

Bites from the genus Phoneutria (Ctenidae, Araneomorpha) are the second most frequent source of spider accidents in Brazil (Gewehr et al., 2013) and are an important public health problem.

\footnotetext{
Abbreviations: AUC, area under the curve; BBB, blood-brain barrier; $\mathrm{Cx} 43$, connexin 43; GFAP, glial fibrillary acidic protein; IL-1 $\beta$, interleukin- $1 \beta$; $\mathrm{IP}_{3}$, inositol 1,4,5-trisphosphate; $I_{3} R$, inositol 1,4,5-trisphosphate receptor; LPS, lipopolysaccharide; PNV, Phoneutria nigriventer venom; TLR4, Toll-like receptor 4 ; TNF- $\alpha$, tumor necrosis factor- $\alpha$.

* Corresponding author.

E-mail address: elisabeth.hansson@neuro.gu.se (E. Hansson).

1 Present address: Department of Animal Physiology and Morphology, Paulista State University (UNESP), 14884-900, Jaboticabal, SP, Brazil; Department of Morphology, UNESP, 14801-903, Araraquara, SP, Brazil.
}

In Phoneutria nigriventer ("armed" spider) envenoming, intense local pain is the major symptom reported by victims (96\% of envenomed patients). Less than $1 \%$ of the accidents cause systemic signs and symptoms, such as arterial hypertension, vomiting, nausea, agitation, vision disturbance, muscle spasm, tremor, profuse sweating, somnolence, tachycardia, tachypnea, priapism and convulsion (Bucaretchi et al., 2000, 2008).

A great number of toxins from $P$. nigriventer venom (PNV) have been isolated and biochemically and pharmacologically characterized. PNV contains neuroactive toxins that block $\mathrm{Ca}^{2+}$ and $\mathrm{K}^{+}$ channels, delay inactivation of $\mathrm{Na}^{+}$channels and act on chemical receptors resulting in neurotransmission disturbances (Gomez et al., 2002; for review see De Lima et al., 2015). The picture of excitotoxicity which characterizes severe envenoming could be accounted for the effects of these neurotoxins named PhTx-1, PhTx2, PhTx-3 and PhTx-4; they exhibit important pharmacological 
properties predicting them a potential source for development of new compounds with biologically-active properties (Escoubas et al., 2000; Grishin, 1999; Rash and Hodgson, 2002).

The systemic administration of the whole venom causes bloodbrain barrier (BBB) breakdown in rats and a series of alterations related to perivascular astrocytes (For review see Cruz-Höfling et al., 2015). These includes swelling of perivascular end-feet (Le Sueur et al., 2003, 2004, 2005; Rapôso et al., 2007, 2012, 2014), upregulations of the glial fibrillary acidic protein (GFAP) and calcium metabolism-associated protein S-100, tumor necrotic factoralpha (TNF- $\alpha$ ) and interferon-gamma (IFN- $\gamma$ ) (Cruz-Höfling et al., 2009), aquaporin-4 (Stávale et al., 2013) and acute, but transient increases in the major gap junction protein connexin 43 (Cx43) (Rapôso et al., 2014). In vitro, PNV promotes the activation of the multi-drug resistance protein (MRP-1), an efflux protein of astrocytes that impedes the access of xenobiotics into the brain (Rapôso et al., 2014). However, the mechanisms involved following the direct impairment of astrocytes by PNV have yet to be described.

Astrocytes are key cellular elements in both tripartite synapses (Santello et al., 2012) and neurovascular units (Bechmann et al., 2007). They exhibit excitability based on the movement of $\mathrm{Ca}^{2+}$ ions through their intracellular compartments and on plasmalemmal $\mathrm{Ca}^{2+}$ influx (Blomstrand et al., 1999). Upon activation by physiological or pathological stimulation, multiple receptors trigger the production of inositol 1,4,5-trisphosphate $\left(\mathrm{IP}_{3}\right)$ and subsequent $\mathrm{IP}_{3}$-induced $\mathrm{Ca}^{2+}$ release from the endoplasmic reticulum (Finkbeiner, 1993).

$\mathrm{Na}^{+} / \mathrm{K}^{+}$-ATPase is an energy-transducing ion pump that indirectly modulates $\mathrm{Ca}^{2+}$ signaling. $\mathrm{Na}^{+} / \mathrm{K}^{+}$-ATPase and the $\mathrm{IP}_{3}$ receptor $\left(\mathrm{IP}_{3} \mathrm{R}\right)$ can form signaling microdomains that influence $\mathrm{Ca}^{2+}$ homeostasis in astrocyte networks in the presence of specific ligands or inflammatory stimuli. Those changes in $\mathrm{Ca}^{2+}$ homeostasis can develop into $\mathrm{Ca}^{2+}$ oscillations (Miyakawa-Naito et al., 2003; Forshammar et al., 2011). Furthermore, an intact cytoskeleton is required for the physiologic propagation of $\mathrm{Ca}^{2+}$ responses (Liu et al., 2007). Ankyrin B, a protein associated with the cytoskeleton, interacts with $\mathrm{Na}^{+} / \mathrm{K}^{+}$-ATPase and with $\mathrm{IP}_{3} \mathrm{R}$, linking the pump to the $\mathrm{Ca}^{2+}$ responses from internal cell stores and the integrity of the cytoskeleton. In addition, astrocytes form physically coupled networks mediated by gap junctions, which facilitate the intercellular transmission of $\mathrm{Ca}^{2+}$ signaling (Cotrina et al., 1998).

Evidence supports an important role for TLRs in the regulation of inflammation and tissue repair. In astrocytes, the stimulation of TLR4 leads to the activation of NF- $\kappa \mathrm{B}$, which regulates the expression of genes involved in immune responses, including cytokines such as TNF- $\alpha$ and interleukin-1 $\beta$ (IL-1 $\beta$ ) (Kielian, 2006).

We hypothesized that astrocytes are one of the targets of PNV and are a component of the toxic mechanism of action of PNV, which induces signs and symptoms related to the CNS. The present study aimed to determine how PNV activates astrocytes using an in vitro model. We studied PNV-evoked $\mathrm{Ca}^{2+}$ responses, changes in the actin cytoskeleton, and alterations in the expression of $\mathrm{Cx}_{\mathrm{X}} 43$, TLR4 and $\mathrm{Na}^{+} / \mathrm{K}^{+}$-ATPase, parameters that interfere to astrocytes and can give a clue how PNV affects astrocytes. To understand the mechanisms underlying PNV-mediated neurotoxicity, we studied glutamate-evoked $\mathrm{Ca}^{2+}$ responses after incubating cultured astrocytes in PNV.

\section{Experimental procedures}

\subsection{Chemicals}

All chemicals were obtained from Sigma-Aldrich (St. Louis, MO, USA), unless stated otherwise. One batch of lyophilized $P$. nigriventer crude venom obtained via electrical stimulation of numerous adult spiders (male and female) was supplied by Professor Evanguedes Kalapothakis (Federal University of Minas Gerais, Belo Horizonte, MG, Brazil). The quality of the venom was evaluated by the observation of experimental envenoming signs in rats: tremors, salivation, flaccid followed by spastic paralysis of legs, respiratory anguish, convulsion and sometimes death (Rapôso et al., 2007). The lyophilized venom was stored at $-20{ }^{\circ} \mathrm{C}$ and was dissolved immediately before use.

\subsection{Primary astrocyte cultures and treatments}

Rat primary cortical astrocytes, Sprague-Dawley rats from embryonic day 19, were purchased from Invitrogen (Thermo Fisher Scientific, Waltham, MA, USA) and prepared according to the manufacturer's instructions with some modifications. Briefly, one vial containing $1 \times 10^{6}$ viable cells was rapidly thawed and gently rinsed with astrocyte growth medium consisting of Dulbecco's modified Eagle medium (DMEM) (high glucose) supplemented with $15 \%$ fetal bovine serum (both from Invitrogen). After centrifugation, the supernatant was removed, and the cells were resuspended in astrocyte growth medium. The cells were plated at a seeding density of $1 \times 10^{4}$ cells per $\mathrm{cm}^{2}$ on an uncoated glass coverslip ( $\mathrm{nr} 1,20 \mathrm{~mm}$ in diameter) (Bergman Labora, Stockholm, Sweden) placed in a 12 -well plate. The cells were incubated at $37{ }^{\circ} \mathrm{C}, 5 \% \mathrm{CO}_{2}$ and $90 \%$ humidity, and the medium was replaced twice a week. The astrocytes were used after 16-17 days in culture.

\subsection{Calcium imaging}

Astrocytes were incubated at room temperature in the $\mathrm{Ca}^{2+}$ sensitive fluorophore Fura-2/AM (Invitrogen Molecular Probes, Eugene, OR, USA) for $30 \mathrm{~min}$ ( $8 \mu \mathrm{l}$ in $990 \mu \mathrm{l} \mathrm{Hank's} \mathrm{HEPES} \mathrm{buffered}$ saline solution [HHBSS], consisting of $137 \mathrm{mM} \mathrm{NaCl}, 5.4 \mathrm{mM} \mathrm{KCl}$,

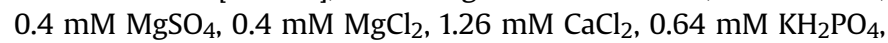
$3.0 \mathrm{mM} \mathrm{NaHCO} 3,5.5 \mathrm{mM}$ glucose, and $20 \mathrm{mM}$ HEPES dissolved in distilled water, $\mathrm{pH}$ 7.4). All substances used during the experiment were diluted in the same solution. The fluorophore was dissolved in $40 \mu \mathrm{l}$ of dimethyl sulfoxide (DMSO) and $10 \mu \mathrm{l}$ of pluronic acid (Molecular Probes, Leiden, The Netherlands). After incubation, the cells were rinsed three times with HHBSS before exposure to PNV. Three different sets of experiments were conducted, with the following aims. 1) To investigate whether PNV directly affects astrocytes and whether the observed effects are dose-dependent, the cells were exposed to three different concentrations of PNV (1.4, 1400 or $14000 \mathrm{ng} / \mathrm{ml}$ ). At $1 \mathrm{~min}$ preceding the start of the experiment, PNV was used as the stimulus. The $14000 \mathrm{ng} / \mathrm{ml}$ is practically the same used in previous in vitro experiments, which used $14.6 \mu \mathrm{g} /$ $\mathrm{ml}$ (Le Sueur et al., 2005); this in vitro concentration had been selected based on in vivo experiments that used a $850 \mu \mathrm{g}$ of PNV per $\mathrm{kg}$ of rat and considered that rats with $250 \mathrm{~g}$ have a plasma volume of $14.5 \mathrm{ml}$ (Filep et al., 1997; Lo and Kaufman, 2001); thus the $14.6 \mu \mathrm{g} / \mathrm{ml}$ concentration for in vitro assays was obtained by applying the in vivo concentration $(850 \mathrm{mg} / \mathrm{kg}=210 \mathrm{mg} \mathrm{PNV} / 250 \mathrm{~g}$ of rat). The in vivo dose of PNV used in rats produced clinical effects similar of those provoked in human accidents graded as severe. 2) To identify the underlying $\mathrm{Ca}^{2+}$ source of the PNV-evoked $\mathrm{Ca}^{2+}$ transients, internal stores were depleted by pre-incubating (30 min, together with Fura-2/AM) the cells in the endoplasmic reticulum $\mathrm{Ca}^{2+}$-ATPase inhibitor thapsigargin $(1 \mu \mathrm{M})$ and caffeine $(20 \mathrm{mM})$ (Sharma and Vijayaraghavan, 2001) or in $\mathrm{Ca}^{2+}$-free buffer (in which $\mathrm{CaCl}_{2}$ was replaced with $\mathrm{MgCl}_{2}$ and $1 \mathrm{mM}$ EGTA). After this pre-incubation, at 1 min preceding the start of the experiment, PNV $(14,000 \mathrm{ng} / \mathrm{ml})$ was used as the stimulus. 3$)$ To investigate how treatment with the receptor antagonist against TLR4 (LPS-RS, $1 \mathrm{ng} /$ $\mathrm{ml}$ ) or $\mathrm{Na}^{+} / \mathrm{K}^{+}$-ATPase (ouabain, $10^{-5} \mathrm{M}$ ) (Harold and Walz, 1992; 
Forshammar et al., 2011) or both affects the PNV-induced $\mathrm{Ca}^{2+}$ transients. The cells were incubated in PNV $(14,000 \mathrm{ng} / \mathrm{ml})$ and LPS$\mathrm{RS}$, ouabain, or both for $5 \mathrm{~h}$ before the experiment. At $1 \mathrm{~min}$ preceding the start of the experiment, glutamate $\left(10^{-3} \mathrm{M}\right)$ was used as the stimulus. The experiments were performed at room temperature using a $\mathrm{Ca}^{2+}$ imaging system, Simple PCI software (Compix Inc., Imaging Systems, Hamamatsu Photonics Management Corporation, Cranberry Twp, PA, USA), and an inverted epifluorescence microscope (Nikon ECLIPSE TE2000-E) equipped with a $20 \times(\mathrm{NA}$ 0.45) fluorescence dry objective lens and a polychrome $\mathrm{V}$ monochromator-based illumination system (TILL Photonics $\mathrm{GmbH}$, Pleasanton, CA, USA). Images were captured using a Hamamatsu C4742-80-12AG camera. The various substances were applied using a peristaltic pump (Instech Laboratories, Plymouth Meeting, PA, USA) at a rate of approximately $600 \mu \mathrm{l} / \mathrm{min}$. The substance took approximately $60 \mathrm{~s}$ to travel through the tubes and reach the cells. The images were captured using an ORCA-12AG (C4742-80-12AG) High Res Digital Cooled CCD Camera (Hamamatsu Photonics Corporation, Hamamatsu, Japan). The total area under the $\mathrm{Ca}^{2+}$ transient curve (AUC), reflecting the amount of $\mathrm{Ca}^{2+}$ released (Berridge, 2007), was analyzed as a measure of the magnitude of the $\mathrm{Ca}^{2+}$ responses using Origin software (Microcal Software Inc., Northampton, MA, USA). The number of peaks was manually calculated for each cell. The area under the $\mathrm{Ca}^{2+}$ peaks was calculated.

In all further experiments when the cells were treated with PNV, $14,000 \mathrm{ng} / \mathrm{ml}$ was used since this was the unique concentration able to induce $\mathrm{Ca}^{2+}$ responses in the astrocytes.

\subsection{Immunocytochemistry and actin visualization}

Astrocytes were incubated in PNV diluted in non-supplemented minimum essential medium (MEM) for $0.5,1,5$ or $24 \mathrm{~h}$. These times represent both the in vivo acute clinical envenoming $(0.5$ and $1 \mathrm{~h})$ and the period of clinical recovery ( 5 and $24 \mathrm{~h}$ ) (Le Sueur et al., 2003; Rapôso et al., 2007). Control (i.e., untreated) cells were maintained in non-supplemented MEM. After the incubation period, the cells were fixed using $4 \%$ paraformaldehyde (Bie \& Berntsen, Herlev, Denmark) for $10 \mathrm{~min}$ and washed twice with phosphate-buffered saline (PBS) (Invitrogen) containing $1 \%$ bovine serum albumin (BSA) (PBS-BSA). The cells were permeabilized using PBS-BSA containing $0.05 \%$ saponin (PBS-BSA-Sap) for $20 \mathrm{~min}$. Thereafter, the cells were incubated for $1 \mathrm{~h}$ in a rabbit polyclonal antibody against GFAP (Dako, Glostrup, Denmark) diluted 1:100 in PBS-BSA-Sap. The cells were washed $3 \times 5 \mathrm{~min}$ with PBS-BSA-Sap and then incubated in a DyLight 594conjugated $\mathrm{F}\left(\mathrm{ab}^{\prime}\right)_{2}$ fragment donkey anti-rabbit IgG secondary antibody (Jackson ImmunoResearch Europe Ltd., Suffolk, UK) diluted 1:150. Nuclei were stained with Hoechst 33258 diluted 1:1000 in the secondary antibody solution. The astrocyte cytoskeleton was stained with an Alexa 488-conjugated phalloidin probe followed by incubation in an Alexa 488-conjugated phalloidin probe (Invitrogen) diluted 1:40 in PBS-BSA. The cells were washed $3 \times 5$ min with PBS-BSA-Sap and then rinsed with PBS. The coverslips were mounted on microscope slides using fluorescent mounting medium (Dako) and viewed under a Nikon Eclipse $80 \mathrm{i}$ microscope. Images were captured using a Hamamatsu C5810 color-intensified 3CCD camera with a $20 \times$ (NA 0.50) plan fluorescence dry objective.

\subsection{G-actin/F-actin detection}

Astrocytes were incubated in PNV diluted in non-supplemented MEM for $0.5,1,5$ or 24 h. Control (i.e., untreated) cells were maintained in non-supplemented MEM. The levels of G-actin and F-actin were measured using a G-actin/F-actin in vivo assay kit
(Cytoskeleton Inc., Denver, CO, USA) according to the manufacturer's instructions. Briefly, the cells were lysed in a detergentbased lysis buffer that stabilizes and maintains the $G$ and $F$ forms of cellular actin. This buffer solubilizes G-actin but not F-actin. An ultracentrifugation step pellets the F-actin and leaves the $\mathrm{G}$-actin in the supernatant. Samples from both the pellet and the supernatant were quantified via Western blot analysis. The G-actin/F-actin ratio was calculated.

\subsection{Sodium dodecyl sulfate-polyacrylamide gel electrophoresis (SDS-PAGE) and western blot}

Astrocytes were incubated in PNV diluted in non-supplemented MEM for $0.5,1,5$ or $24 \mathrm{~h}$. Control (i.e., untreated) cells were maintained in non-supplemented MEM. Then, the cells were rinsed twice in PBS and immediately lysed for 20 min on ice in cold radioimmunoprecipitation assay (RIPA) lysis buffer containing $150 \mathrm{mM}$ $\mathrm{NaCl}, 1 \%$ IGEPAL ${ }^{\circledR} \mathrm{CA}-630,0.5 \%$ sodium deoxycholate, $0.1 \%$ SDS, and $50 \mathrm{mM}$ Tris ( $\mathrm{pH}$ 8.0) supplemented with a protease inhibitor cocktail containing $104 \mathrm{mM}$ AEBSF, $80 \mathrm{mM}$ aprotinin, $4 \mathrm{mM}$ bestatin, $1.4 \mathrm{mM}$ E-64, $2 \mathrm{mM}$ leupeptin, and $1.5 \mathrm{mM}$ pepstatin A. The procedure was performed as described by Persson et al. (2005). Separate aliquots were collected to determine the protein concentration. All of the samples were analyzed for the total protein content, and $20 \mu \mathrm{g}$ of total protein from each sample was loaded on each lane of the gel. $\beta$-actin was used as a loading control. SDS-PAGE was conducted using the Novex pre-cast gel system (Invitrogen) according to the manufacturer's recommendations using $4-12 \%$ Bis-Tris gels (Invitrogen) at $200 \mathrm{~V}$ for $50 \mathrm{~min}$. The separated proteins were transferred at $30 \mathrm{~V}$ for $60 \mathrm{~min}$ to a nitrocellulose membrane (Invitrogen) in NuPAGE transfer buffer (Invitrogen) supplemented with methanol and NuPAGE antioxidant (Invitrogen). The membranes were rinsed twice with distilled water, and the proteins were visualized using Ponceau S solution (Sigma). The proteins were blocked with $0.5 \%$ fat-free skim milk (Semper AB, Sundbyberg, Sweden) in Tris-buffered saline (TBST; $50 \mathrm{mM}$ Tris- $\mathrm{HCl}, 150 \mathrm{mM} \mathrm{NaCl}$, and $0.05 \%$ Tween) for $60 \mathrm{~min}$ at room temperature. The membranes were probed using the following antibodies: mouse monoclonal anti- $\mathrm{Na}^{+} / \mathrm{K}^{+}$-ATPase $(\alpha$ Subunit) 1:250, rabbit polyclonal anti-TLR4 1:500 (Santa Cruz Biotechnology, Dallas, TX, USA), rabbit polyclonal anti-Cx43 1:125 (Invitrogen) and mouse monoclonal anti- $\beta$-actin 1:5000. Next, the membranes were washed $4 \times 2$ min with TBST and incubated in a horseradish peroxidase (HRP)-conjugated secondary antibody, either $\left.\mathrm{F}(\mathrm{ab})_{2}\right)_{2}$ fragment donkey anti-mouse or $\mathrm{F}\left(\mathrm{ab}^{\prime}\right)_{2}$ fragment donkey anti-rabbit diluted 1:10,000 (Jackson ImmunoResearch), followed by several washes with TBST. All of the primary and secondary antibodies were diluted in $0.5 \%$ fat-free skim milk in TBST. The antibody-bound protein was detected using an enhanced chemiluminescence kit (Millipore Corp., Billerica, MA, USA) and was visualized using a Fuji Film LAS-3000 image analyzer (Tokyo, Japan).

\subsection{Total protein determination}

The protein content was determined using a detergentcompatible (DC) protein assay (Bio-Rad, Hercules, CA, USA) in accordance with the manufacturer's instructions based on the method described by Lowry et al. (1951) with minor modifications. The standards (0-4 mg/mL BSA) and samples were mixed with the reagents, incubated for $15 \mathrm{~min}$ at room temperature, measured at $750 \mathrm{~nm}$ using a Versa-max microplate reader and analyzed using SoftMax Pro 4.8 software (Molecular Devices, Sunnyvale, CA, USA). 

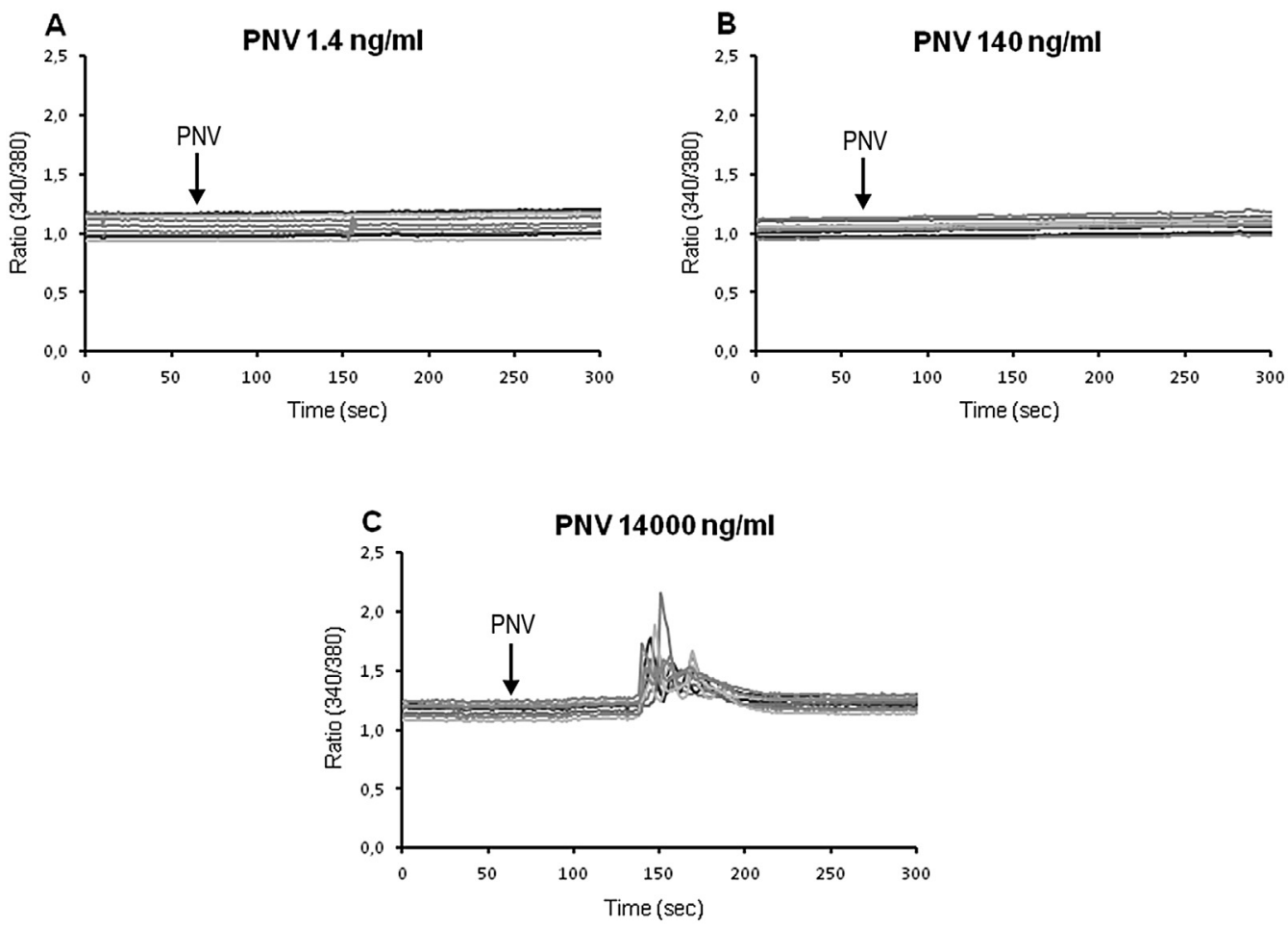

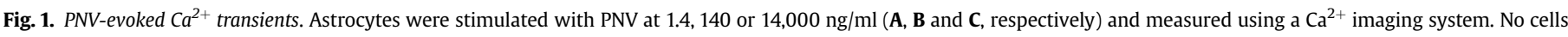

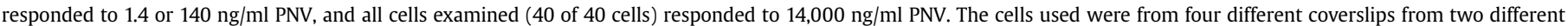
seeding times, $\mathrm{n}=4$. The results shown are from a representative experiment.
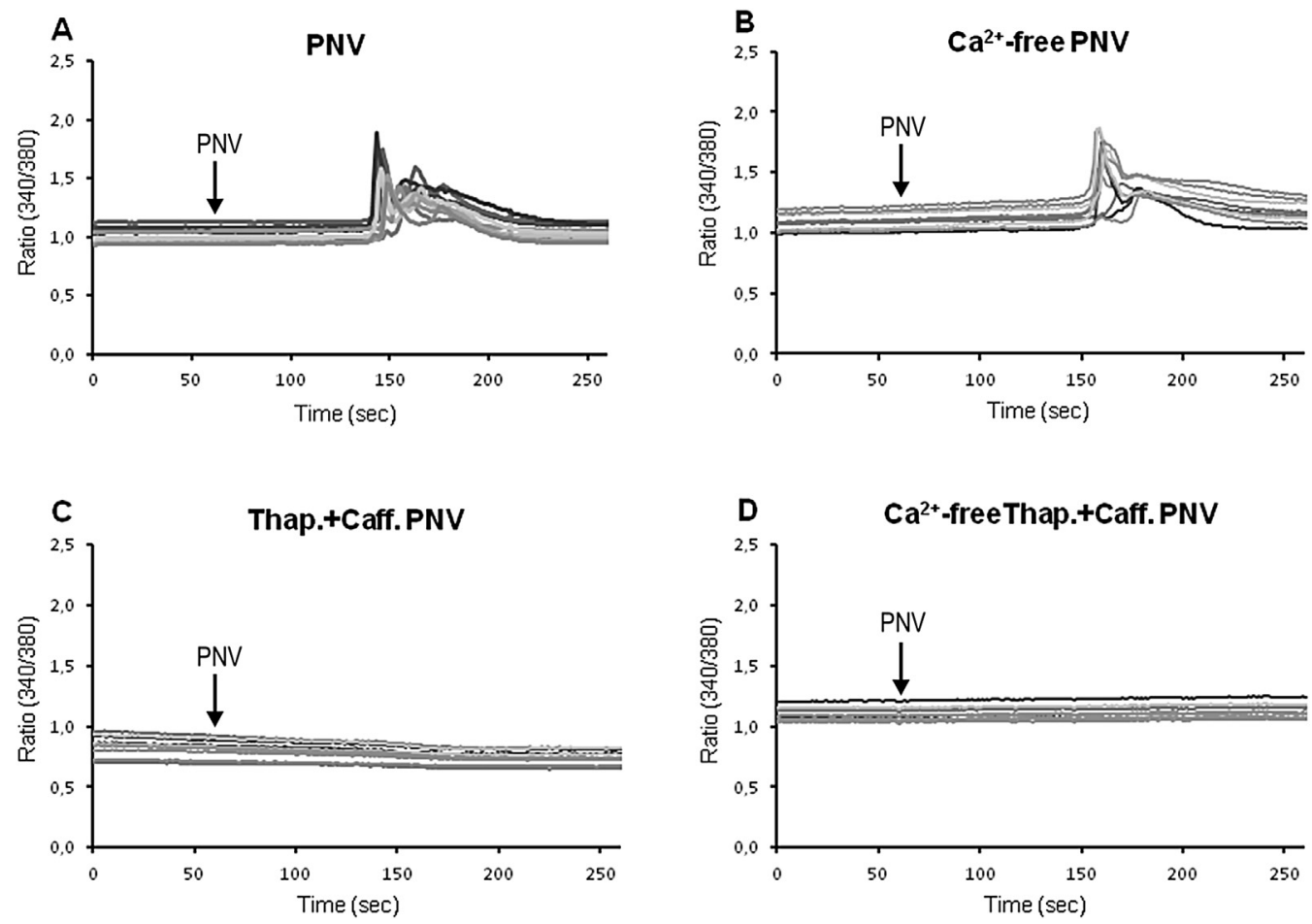

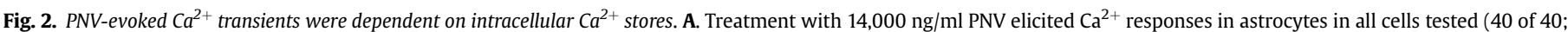

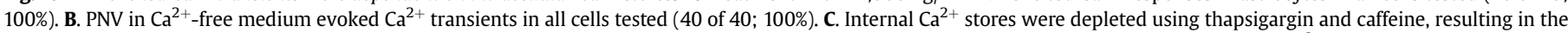

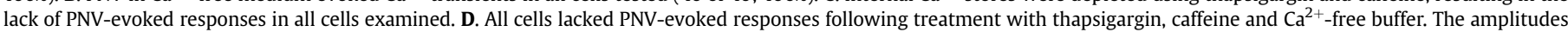

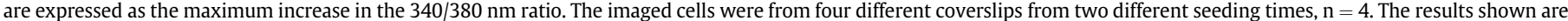
from a representative experiment. 


\subsection{Statistics}

The level of significance was analyzed using one-way analysis of variance (ANOVA) followed by Dunnett's multiple comparisons test. The error bars show the standard error of the mean (SEM). Unpaired Student's t-tests were used to compare each treatment with the control.

\section{Results}

\subsection{PNV-evoked $\mathrm{Ca}^{2+}$ transients}

$\operatorname{PNV}(1.4,140$ or $14,000 \mathrm{ng} / \mathrm{ml})$ was used as stimulator and $\mathrm{Ca}^{2+}$ imaging experiments were performed. PNV at $1.4 \mathrm{ng} / \mathrm{ml}$ or $140 \mathrm{ng} /$ $\mathrm{ml}$ did not stimulate the cells. However, PNV at $14,000 \mathrm{ng} / \mathrm{ml}$ induced a strong and rapid response in $100 \%$ of the examined cells (40 of 40 cells) (Fig. $1 \mathrm{~A}-\mathrm{C}$ ). This concentration was used in all further experiments. To investigate whether PNV-evoked $\mathrm{Ca}^{2+}$ signaling was cross-membrane or intracellular, the cells were incubated in $\mathrm{Ca}^{2+}$-free buffer for $30 \mathrm{~min}$ before stimulation and during the experiment. Other cells were incubated in a cocktail of thapsigargin and caffeine for $30 \mathrm{~min}$ before the experiment to empty the internal store of $\mathrm{Ca}^{2+}$ from the endoplasmic reticulum. The $\mathrm{Ca}^{2+}$-free buffer did not change the PNV-induced $\mathrm{Ca}^{2+}$ responses; all cells ( 40 of 40 cells) responded to PNV in the same pattern as the cells treated with the standard buffer. However, none of the 40 cells treated with thapsigargin and caffeine responded to PNV stimulation, indicating that PNV induces $\mathrm{Ca}^{2+}$ responses due to efflux from storage in the endoplasmic reticulum and that this venom targets some membrane receptor in astrocytes. A control

\section{PNV Ca ${ }^{2+}$ responses}
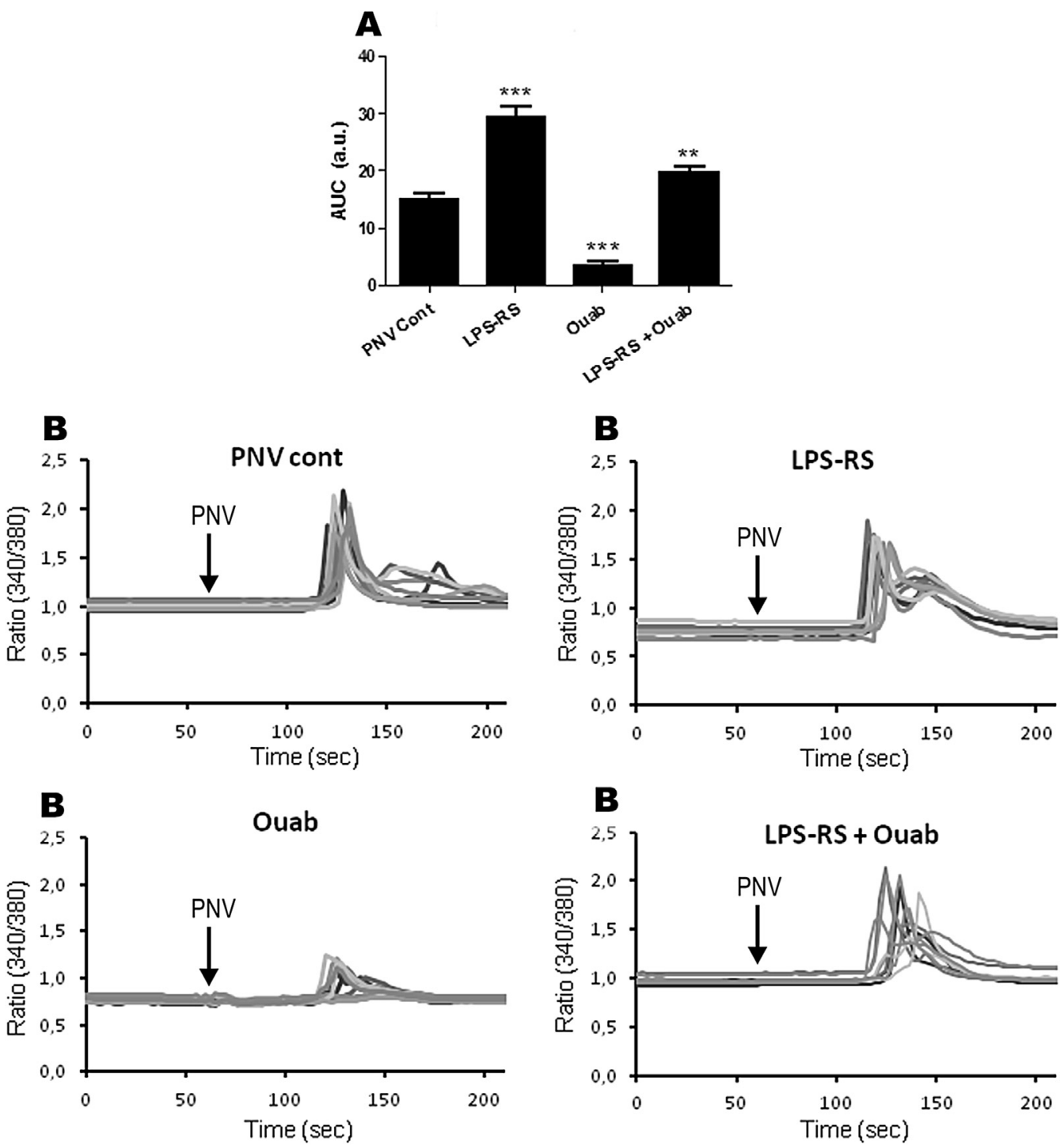

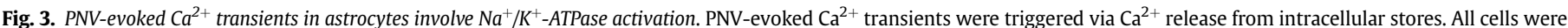

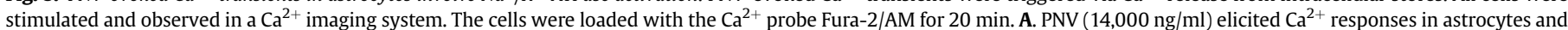

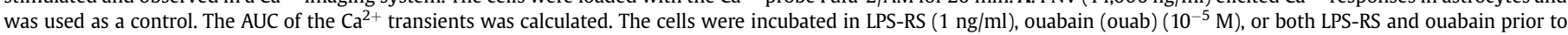

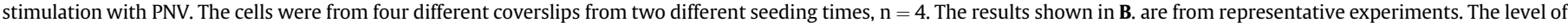

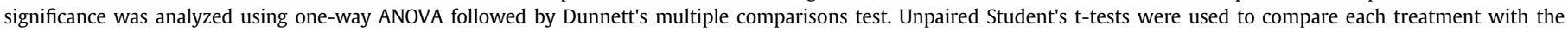
control. ${ }^{* *} \mathrm{P}<0.01$ and ${ }^{* * *} \mathrm{P}<0.001$ compared to the PNV-treated cells (PNV cont). 


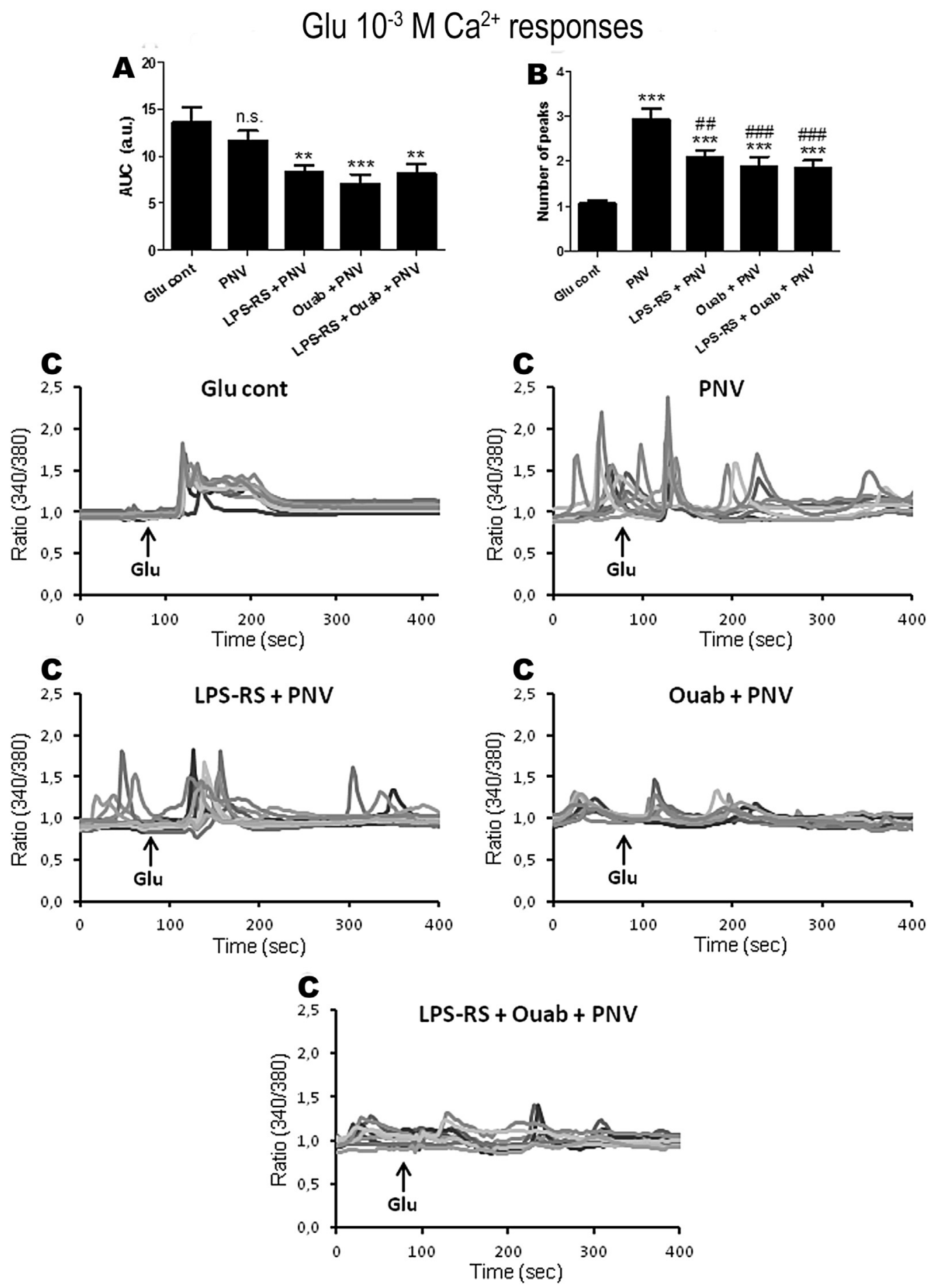

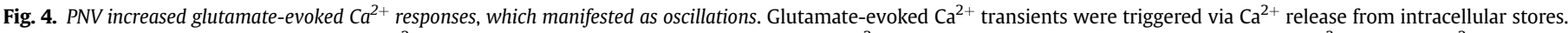

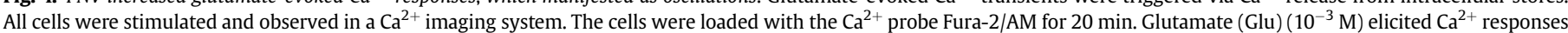

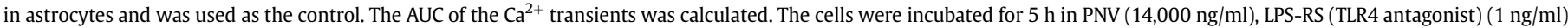

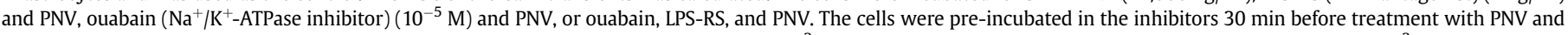

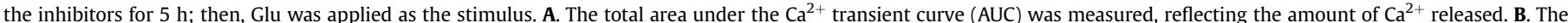

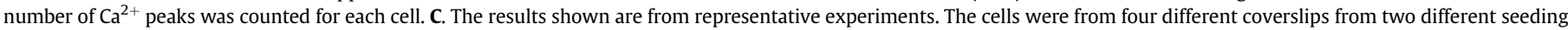

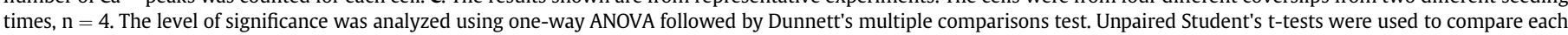

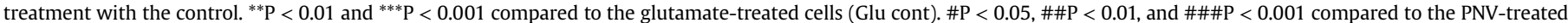
cells (PNV).

experiment was performed in which the cells were incubated in both $\mathrm{Ca}^{2+}$-free medium and thapsigargin/caffeine, and no cells responded to PNV stimulation (Fig. $2 \mathrm{~A}-\mathrm{D}$ ).
To search for possible target receptors of PNV, the cells were treated with the TLR4 antagonist LPS-RS or the $\mathrm{Na}^{+} / \mathrm{K}^{+}$-ATPase inhibitor ouabain for $30 \mathrm{~min}$ before PNV stimulation and during the 

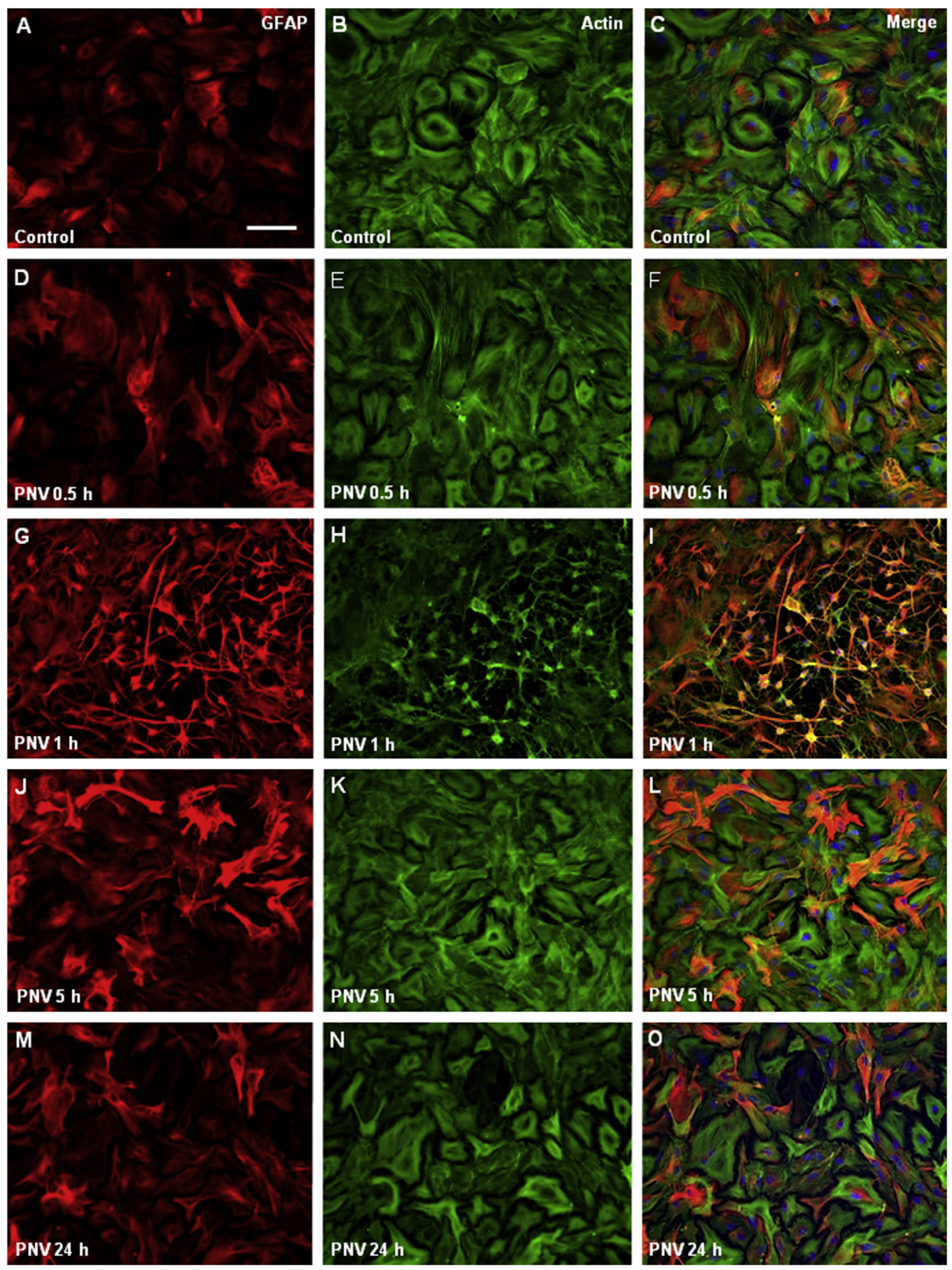

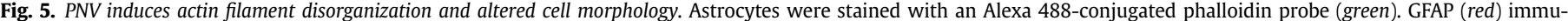

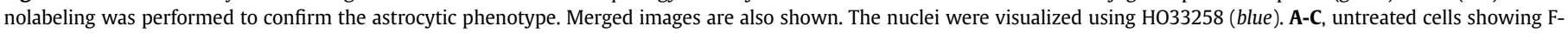

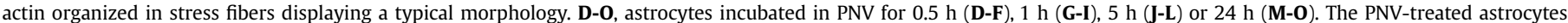

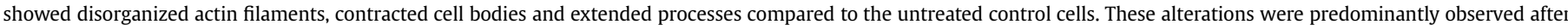

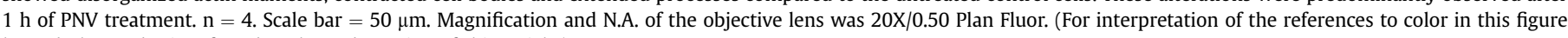
legend, the reader is referred to the web version of this article.)

entire experiment (Fig. 3 A-E). All cells ( 40 of 40 cells) responded to PNV stimulation in the PNV control group (Fig. 3B). Treatment with LPS-RS (Fig. 3C) induced a significant increase in PNV-evoked $\mathrm{Ca}^{2+}$ transients in all cells measured (40 of 40 cells) $(\mathrm{P}<0.001)$ compared to the control treatment. Compared to the control treatment, ouabain treatment (Fig. 3D) caused a significant decrease in the response to PNV ( $\mathrm{P}^{<} 0.001$ ), and only $57.5 \%$ of the cells (23 of 40 cells) responded to PNV stimulation. Compared to the control treatment, pretreatment with a mixture of both inhibitors (Fig. 3E) induced an increase in the $\mathrm{Ca}^{2+}$-evoked transients
$(\mathrm{P}<0.01)$ in all cells measured (40 of 40 cells).

\subsection{PNV increased glutamate-evoked $\mathrm{Ca}^{2+}$ responses}

To investigate whether PNV induces changes in the response to glutamate stimulation, astrocytes were incubated in PNV alone or with a receptor inhibitor (LPS-RS or ouabain) (Fig. 4 A-B). The control-treated astrocytes (stimulated with glutamate) showed a typical response, as $88.3 \%$ of the cells ( 53 of 60 cells) responded to glutamate stimulation by exhibiting $\mathrm{Ca}^{2+}$ oscillations. Following 
PNV pretreatment, the AUC was not changed compared with the control treatment; however, the number of $\mathrm{Ca}^{2+}$ peaks was significantly increased $(P<0.001)$, and all (60 of 60$)$ cells responded to glutamate stimulation. Incubation in PNV and LPS-RS (TLR4 antagonist) induced a significant decrease in the AUC $(\mathrm{P}<0.01)$ compared with the control treatment. Additionally, the number of $\mathrm{Ca}^{2+}$ peaks in the PNV- and LPS-RS-treated cells was significantly increased $(P<0.001)$ compared with that in the control-treated cells but was decreased when compared with that in the PNVtreated cells $(P<0.01)$. In this group, 90\% of the cells responded to glutamate stimulation (54 of 60 cells). In the cells treated with PNV and ouabain, the AUC was decreased $(\mathrm{P}<0.001)$ compared with control cells. The number of $\mathrm{Ca}^{2+}$ peaks in the PNV- and ouabain-treated cells was increased compared to that in the control cells $(\mathrm{P}<0.001)$ but was decreased compared to that in the PNVtreated cells $(\mathrm{P}<0.001) ; 78.3 \%$ of the PNV- and ouabain-treated cells (47 of 60 cells) responded to glutamate stimulation. Astrocytes treated with PNV, LPS-RS and ouabain also showed a significantly decreased AUC $(P<0.01)$ compared with the control cells. The number of $\mathrm{Ca}^{2+}$ peaks was increased in the PNV-, LPS-RS- and ouabain-treated cells compared with that in the control-treated cells $(\mathrm{P}<0.001)$ but was decreased compared with that in the PNV-treated cells $(\mathrm{P}<0.001)$; in this group, $83.3 \%$ of the cells responded (50 of 60 cells).

\subsection{Actin filaments}

To determine whether PNV induces changes in actin filament morphology, astrocytes were incubated in PNV for $0.5,1,5$ or $24 \mathrm{~h}$. All cells were GFAP-positive, and the untreated (control) cultures predominantly contained F-actin organized in stress fibers. The cells incubated in PNV for $0.5 \mathrm{~h}$ showed a discrete contraction of the cell bodies and actin filaments that were more tightly organized (forming ring structures) around their nucleus. Astrocytes treated with PNV for $1 \mathrm{~h}$ showed the most evident changes in morphology and in the distribution of stress fibers. The cell bodies were retracted and extended more visible and longer processes. However, the actin filaments were not diffuse or disorganized. After $5 \mathrm{~h}$ of incubation in PNV, the cells were less retracted, and after $24 \mathrm{~h}$, their contraction was similar to that of the control cells (Fig. $5 \mathrm{~A}-\mathrm{O}$ ).

\subsection{G-actin/F-actin ratio}

Because the cells showed morphologic changes, including the retraction of cell bodies and in the alteration of stress fiber distribution, the G-actin/F-actin ratio was calculated. The G-actin/F-actin ratio was decreased in the cells treated with PNV (significant difference after treatment for $0.5 \mathrm{~h} ; \mathrm{P}<0.01$ ), indicating that PNV induces an increase in F-actin (Fig. 6), probably via the formation of ring structures.

\section{5. $\mathrm{Na}^{+} / \mathrm{K}^{+}$-ATPase, TLR4 and $\mathrm{C} \times 43$ expression}

The time course of the expression of two isoforms of $\mathrm{Na}^{+} / \mathrm{K}^{+}-$ ATPase (95 and $70 \mathrm{kDa}$ ) was investigated. The expression of both isoforms was significantly increased $(\mathrm{P}<0.05$ and $\mathrm{P}<0.01$ for 95 and $70 \mathrm{kDa}$, respectively) after $5 \mathrm{~h}$ of PNV incubation (Fig. $7 \mathrm{~A}$ and B).

Compared with the control treatment, TLR4 expression was significantly decreased after PNV treatment for all investigated periods ( $\mathrm{P}<0.05$ for 0.5 and $1 \mathrm{~h} ; \mathrm{P}<0.01$ for 5 and $24 \mathrm{~h}$ ) (Fig. $7 \mathrm{C}$ ).

Because astrocyte networks depend on the integrity of gap junctions, the expression of $\mathrm{Cx} 43$ (the primary protein in astrocyte gap junctions) was investigated. The $\mathrm{Cx} 43$ levels were significantly increased after $0.5,1$ or $5 \mathrm{~h}(\mathrm{P}<0.05$ ) of exposure to PNV (Fig. $7 \mathrm{D}$ ).

\section{Discussion}

The results in the present study show that PNV directly activates astrocytes in a dose-dependent manner. Low PNV concentrations ( 1.4 and $140 \mathrm{ng} / \mathrm{ml}$ ) were not able to activate these cells, but $14,000 \mathrm{ng} / \mathrm{ml} \mathrm{PNV}$ induced $\mathrm{Ca}^{2+}$ responses in astrocytes. This concentration is coherent with Le Sueur et al. (2005). The authors used a similar concentration $(14.6 \mu \mathrm{g} / \mathrm{ml})$ in different cell lines (ECV304, C6 glioma and MDCK). The venom composition has some variation considering male or female, temperature and season. To solve this problem, the best way was to make a pool mixing venom from male and female spiders, in controlled environmental conditions (Le Sueur et al., 2003, 2004; Rapôso et al., 2007, 2012; 2014; Cruz-Höfling et al., 2009).

These $\mathrm{Ca}^{2+}$ transients were originated from internal $\mathrm{Ca}^{2+}$ stores because PNV induced the same $\mathrm{Ca}^{2+}$ oscillations in a $\mathrm{Ca}^{2+}$-free buffer and because endoplasmic reticulum $\mathrm{Ca}^{2+}$ depletion via treatment of the cells with thapsigargin and caffeine abolished these PNV-evoked responses. The results indicated that PNV activates astrocytes via membrane receptors and intracellular $\mathrm{Ca}^{2+}$ stores.

To investigate the mechanisms underlying PNV-evoked $\mathrm{Ca}^{2+}$ transients in astrocytes, the membrane receptors $\mathrm{Na}^{+} / \mathrm{K}^{+}$-ATPase and TLR4 were assessed. The expression of $\mathrm{Na}^{+} / \mathrm{K}^{+}$-ATPase was increased by PNV after $5 \mathrm{~h}$ of incubation. When the pump was blocked using ouabain, the PNV-evoked $\mathrm{Ca}^{2+}$ responses were decreased. These findings suggested that $\mathrm{Na}^{+} / \mathrm{K}^{+}$-ATPase may be a target of PNV. Other types of venom can generate $\mathrm{Ca}^{2+}$ responses and target $\mathrm{Na}^{+} / \mathrm{K}^{+}$-ATPase and the cytoskeleton. At picomolar concentrations, the highly potent marine toxin palytoxin (PTX) binds to $\mathrm{Na}^{+} / \mathrm{K}^{+}$-ATPase and converts it to a nonselective cation channel (Habermann, 1989). Bothrops alternatus snake venom has been shown to cause marked cytoskeletal, morphological and renal functional alterations, along with the enhancement of $\mathrm{Na}^{+} / \mathrm{K}^{+}-$ ATPase expression and activity during the early phase $(6 \mathrm{~h})$ of envenoming (Linardi et al., 2011). Peptides from the venom of the scorpions Parabuthus schlechteri and Opistophthalmus carinatus increase the intracellular $\mathrm{Ca}^{2+}$ concentration due to both the release of $\mathrm{Ca}^{2+}$ from intracellular stores and the influx of $\mathrm{Ca}^{2+}$ from the extracellular space. These $\mathrm{Ca}^{2+}$ responses were pertussis toxinsensitive, suggesting the involvement of $G$ proteins (Moerman et al., 2003). The venom of the scorpion Tityus serrulatus causes $\mathrm{Ca}^{2+}$ oscillations and morphological changes in macrophages due to cytoskeletal reorganization (Petricevich et al., 2008). The venom

\section{G-actin/F-actin}

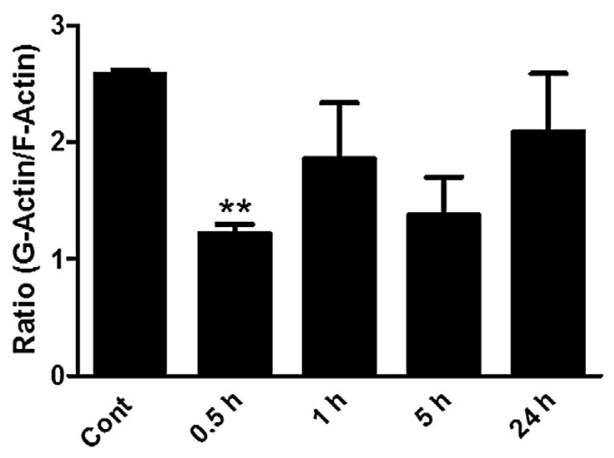

Fig. 6. The G-actin/F-actin ratio was altered due to PNV exposure. The G-actin/F-actin ratio was measured in untreated (control) cells and in cells treated with PNV for $0.5,1$, 5 or $24 \mathrm{~h}$. This ratio was significantly changed in astrocytes incubated in PNV for $0.5 \mathrm{~h}$. $\mathrm{n}=3$. The level of significance was analyzed using one-way ANOVA followed by Dunnett's multiple comparisons test. Unpaired Student's t-tests were used to compare each treatment with the control. ${ }^{* *} \mathrm{P}<0.01$ compared to the untreated control cells. 

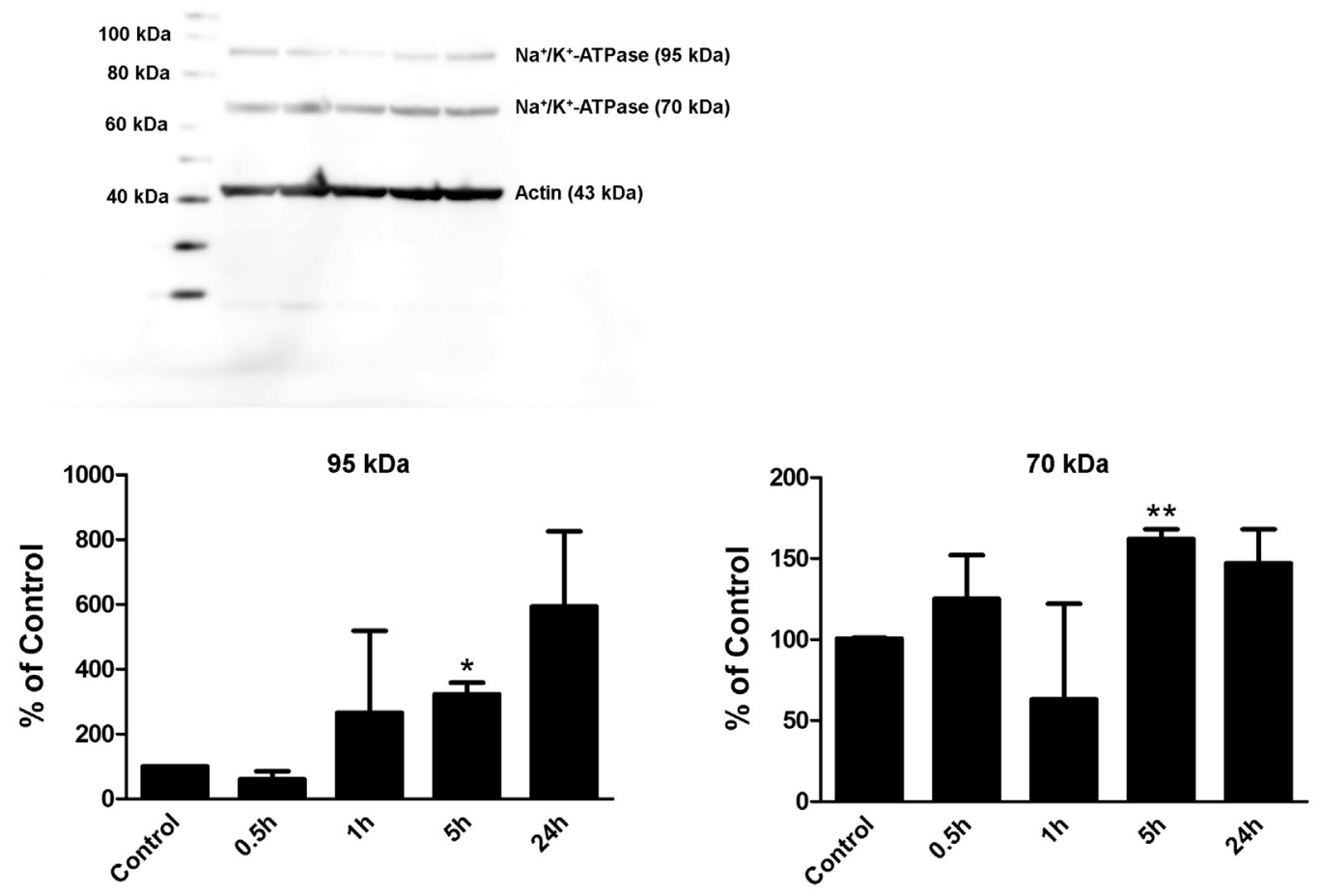

TLR4
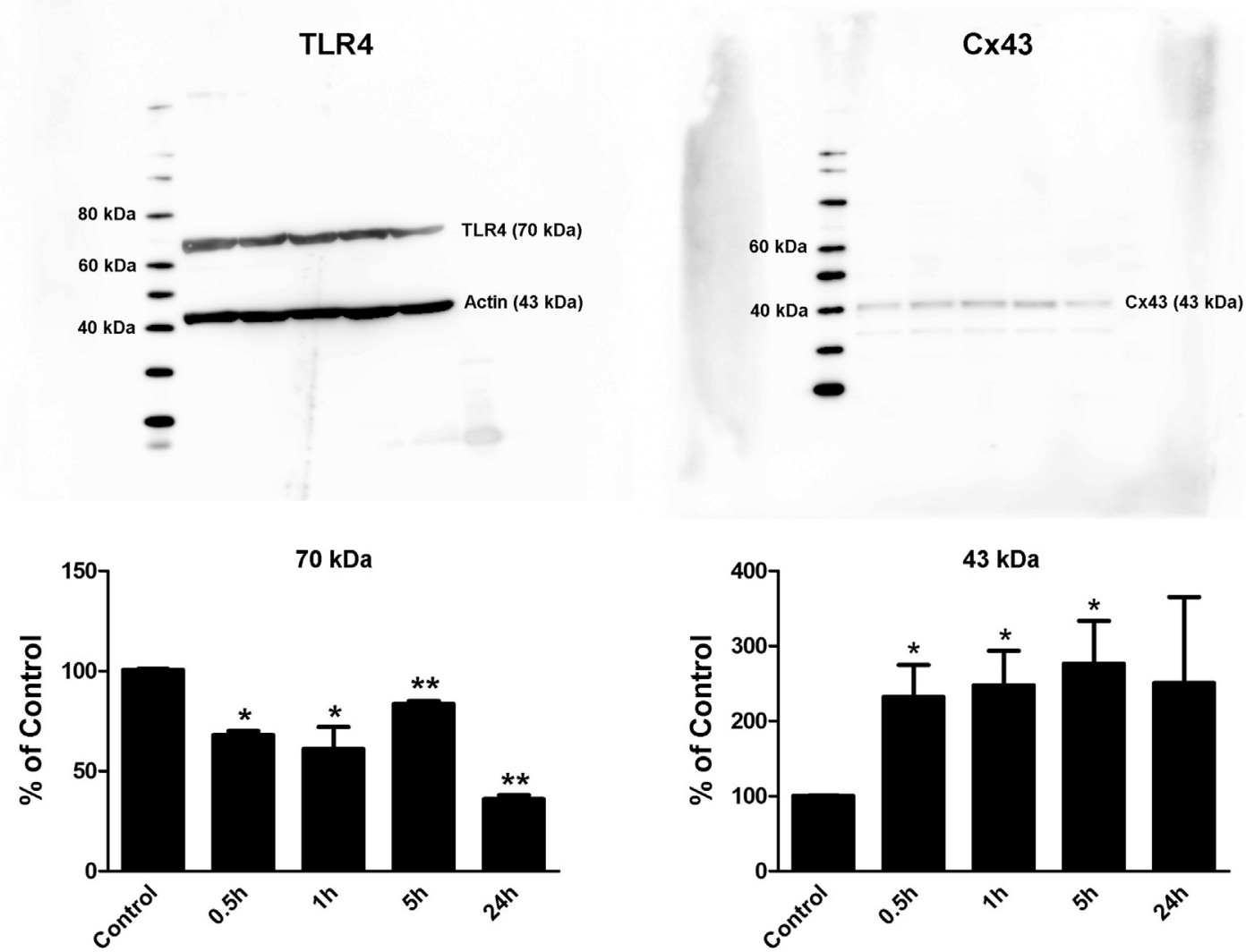

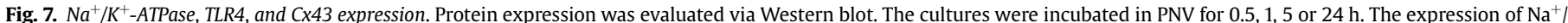

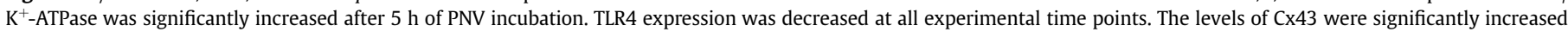

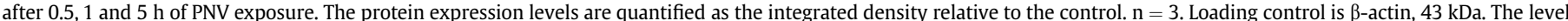

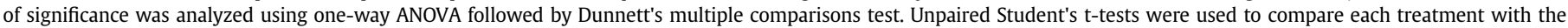
control. ${ }^{*} \mathrm{P}<0.05$ and ${ }^{* *} \mathrm{P}<0.01$ compared to the untreated control cells. 
of the brown spider Loxosceles intermedia also induces morphological alterations, such as cell retraction and increased filopodial projections, in endothelial cells (Paludo et al., 2006). In addition, peptides from the venom of the scorpion Orthochirus scrobiculosus induce morphological changes and polymerization of the cytoskeletal protein G-actin into F-actin (Tiras et al., 2004).

In addition, the expression of TLR4 was decreased due to PNV treatment, indicating that PNV may act as a TLR4 inhibitor. When astrocytes were pre-incubated with the TLR4 antagonist LPS-RS, the PNV-evoked $\mathrm{Ca}^{2+}$ responses were increased. No detectable cytokine release from astrocytes after venom incubation was observed. This result may be because TLR4 expression was decreased by PNV stimulation.

PNV activates $\mathrm{Na}^{+} / \mathrm{K}^{+}$-ATPase and inhibits TLR4, and the activities of PNV represent a dual mechanism for activating $\mathrm{Na}^{+} / \mathrm{K}^{+}$ATPase. We hypothesize that TLR4 interacts with $\mathrm{Na}^{+} / \mathrm{K}^{+}$-ATPase in some fashion; potentially, TLR4 physiologically inhibits $\mathrm{Na}^{+} / \mathrm{K}^{+}-$ ATPase. This interaction between TLR4 and $\mathrm{Na}^{+} / \mathrm{K}^{+}$-ATPase is uncertain and needs to be investigated.

However, PNV clearly affected the response of astrocytes to glutamate. PNV changed the glutamate-evoked $\mathrm{Ca}^{2+}$ transients from individual peaks to $\mathrm{Ca}^{2+}$ oscillations. Toxins from PNV inhibit glutamate uptake (Reis et al., 2000). This effect of PNV may explain the oscillatory $\mathrm{Ca}^{2+}$ response to glutamate. When astrocytes were treated with ouabain and PNV, the number of $\mathrm{Ca}^{2+}$ peaks and the AUC decreased, indicating a less oscillatory and less intense $\mathrm{Ca}^{2+}$ response. One possible explanation may be the desensitization of metabotropic glutamate receptors (mGluRs). It was demonstrated that mGluR5 may serve as a target of ouabain and the endogenous $\mathrm{Na}^{+} / \mathrm{K}^{+}$-ATPase inhibitor endobain E (Calviño et al., 2002), suggesting that endobain $\mathrm{E}$ and ouabain induce $\mathrm{mGluR}$ desensitization similar to that induced by high agonist concentrations (RodríguezMoreno et al., 1998).

Treatment with LPS-RS and PNV also decreased the responses to glutamate. This result may be due to an interaction between TLR4 and $\mathrm{Na}^{+} / \mathrm{K}^{+}$-ATPase. By inhibiting TLR4, $\mathrm{Na}^{+} / \mathrm{K}^{+}$-ATPase becomes activated, altering glutamate uptake. These results also support the hypothesis that TLR4 interacts with $\mathrm{Na}^{+} / \mathrm{K}^{+}$-ATPase.

Intracellular $\mathrm{Ca}^{2+}$ transients regulate several responses within cells, as well as the communication between cells. The processes regulated by $\mathrm{Ca}^{2+}$ signaling include cell cycle regulation, differentiation, programmed cell death, neurotransmission, cell motility/ migration and cell morphology (Schwaller, 2012). The present results showed that PNV induces morphological changes in astrocytes. These cells clearly contracted after PNV incubation (for $0.5,1$, 5 or $24 \mathrm{~h}$ ); after $1 \mathrm{~h}$ of PNV incubation, the retraction of the cell bodies and the extension of processes were the most evident. This effect was accompanied by an alteration in the arrangement of actin filaments and by a decrease in the G-actin/F-actin ratio, indicating an increase in F-actin formation. The changes in both, morphology and actin filaments, were self-regulated, showing a restoration after some hours. It has been demonstrated that PNV effects in in vivo experimental models are acute and transients (Rapôso et al., 2007, 2012; 2014). In addition, $\mathrm{Na}^{+} / \mathrm{K}^{+}$-ATPase may be involved in cytoskeletal changes. It has been reported that the actin cytoskeleton is critical for maintaining cell structure and function, cell polarity and the appropriate localization and function of critical proteins such as $\mathrm{Na}^{+} / \mathrm{K}^{+}$-ATPase (Molitoris, 1991). Ankyrins are a ubiquitously expressed intracellular scaffolding protein family associated with a diverse set of membranes and cytoskeletal and cytoplasmic proteins. Both Ank-B and Ank-G have been reported to interact with $\mathrm{Na}^{+} / \mathrm{K}^{+}$-ATPase. Additionally, Ank-B has been reported to interact with $\mathrm{IP}_{3} \mathrm{R}$ (Lencesova et al., 2004; Mohler et al., 2005). Thus, the signaling microdomain consisting of $\mathrm{Na}^{+} / \mathrm{K}^{+}$-ATPase, Ank-B and $\mathrm{IP}_{3} \mathrm{R}$ may be related to the cytoskeleton and to the morphological changes induced by PNV in astrocytes.

Gap junctions were also investigated in the present study through Cx43 expression. Cell-cell communication by astrocytes primarily involves direct signaling due to the exchange of $\mathrm{Ca}^{2+}$ via gap junctions (the propagation of intercellular $\mathrm{Ca}^{2+}$ responses). The present study showed that PNV induces an increase in $\mathrm{Cx} 43$ expression (the predominant connexin in the CNS) after $0.5,1$ or $5 \mathrm{~h}$ of venom exposure. It has been reported that $\mathrm{Ca}^{2+}$ responses, which disseminate to neighboring astrocytes via gap junctions, upregulate GFAP expression (Gao et al., 2013). It was previously demonstrated that PNV induced increased GFAP expression (reactive gliosis) in an envenoming animal model (Cruz-Höfling et al., 2009) and that this increase occurred simultaneously with Cx43 upregulation (Rapôso et al., 2014).

In addition, the upregulation of $\mathrm{Cx} 43$ corresponds to the formation of hemichannels. These $\mathrm{Cx} 43$ hemichannels open into the extracellular space. Recent studies indicated that, during inflammation, hemichannels open and facilitate the two-way communication between the intracellular and extracellular milieus (Sáez et al., 2003). It was demonstrated that inflammatory stimuli induce a dual regulation of $\mathrm{Cx} 43$ channels: an inhibition of gap junction activity and an increase in hemichannel activity.

The observed neuropharmacological effects can be due to one or several toxins from PNV. This first paper gives information about the effects of the total venom in astrocytes. This is important, since the intoxications by accidental bites in human or animals are due to the whole venom action. Therefore, this study contributes to clarify the mechanisms of envenoming and to develop new treatments. On the other hand, to determine what toxin or toxins are responsible for the presented effects is important, since the venom components can be useful as a prototype for drug development and to develop research models. Further studies with toxins will be done to give more information.

\section{Conclusion}

In conclusion, astrocytes are direct targets of PNV. PNV induces changes in astrocytes that may contribute to the neurotoxic effects and excitatory signals observed following $P$. nigriventer envenomation. PNV was used as a tool to demonstrate, for the first time, that some interaction can be occurring between TLR4 and $\mathrm{Na}^{+} / \mathrm{K}^{+}$ATPase. In addition, PNV may be a useful tool for studying the correlation between $\mathrm{Ca}^{2+}$ responses, $\mathrm{Na}^{+} / \mathrm{K}^{+}$-ATPase activity and cytoskeletal functions in astrocytes. At present, there are no specific therapies for PNV-induced neurotoxicity. Local anesthetics, opioids and non-steroidal anti-inflammatory drugs have been used empirically. $\mathrm{Na}^{+} / \mathrm{K}^{+}$-ATPase may be a more specific drug target for controlling the neurotoxic effects of $P$. nigriventer envenomation.

\section{Conflict of interest statement}

The authors declare no conflicts of interest.

\section{Acknowledgments}

The authors thank Fundação de Amparo à Pesquisa do Estado de São Paulo (FAPESP \#2012/19245-0, \#2011/08005-6) and Conselho Nacional de Desenvolvimento Científico e Tecnológico (CNPq \#305099/2011-6 and \#486142/2012-4) in Brazil and Edit Jacobson's Foundation and the Sahlgrenska University Hospital (LUA/ALF GBG11587) in Gothenburg, Sweden, and AFA Insurance, Stockholm, Sweden, for financial support. 


\section{References}

Bechmann, I., Galea, I., Perry, V.H., 2007. What is the blood-brain barrer (not)? Trends Immunol. 28, 5-11.

Berridge, M.U., 2007. Inositol trisphosphate and calcium oscillations. Biochem. Soc. Symp. 74, 1-7.

Blomstrand, F., Aberg, N.D., Eriksson, P.S., Hansson, E., Rönnbäck, L., 1999. Extent of intercellular calcium wave propagation is related to gap junction permeability and level of connexin-43 expression in astrocytes in primary cultures from four brain regions. Neurosci 92, 255-265.

Bucaretchi, F., Deus Reinaldo, C.R., Hyslop, S., Madureira, P.R., De Capitani, E.M., Vieira, R.J., 2000. A clinico-epidemiological study of bites by spiders of the genus Phoneutria. Rev. Inst. Med. Trop. Sao Paulo 42, 17-21.

Bucaretchi, F., Mello, S.M., Vieira, R.J., Mamoni, R.L., Blotta, M.H., Antunes, E. Hyslop, S., 2008. Systemic envenomation caused by the wandering spider Phoneutria nigriventer, with quantification of circulating venom. Clin. Toxicol. (Phila) 46, 885-889.

Calviño, M.A., Peña, C., Rodíguez de Lores Arnaiz, G., 2002. Metabotropic glutamate receptor involvement in phosphoinositide hydrolysis stimulation by an endogenous $\mathrm{Na}(+), \mathrm{K}(+)$-ATPase inhibitor and ouabain in neonatal rat brain. Brain Res. Dev. Brain Res. 138, 167-175.

Cotrina, M.L., Lin, J.H., Alves-Rodrigues, A., Liu, S., Li, J., Azmi-Ghadimi, H., Kang, J., Naus, C.C., Nedergaard, M., 1998. Connexins regulate calcium signaling by controlling ATP release. Proc. Natl. Acad. Sci. U. S. A. 95, 15735-15740.

Cruz-Höfling, M.A., Rapôso, C., Verinaud, L., Zago, G.M., 2009. Neuroinflammation and astrocytic reaction in the course of Phoneutria nigriventer (armed-spider) blood-brain barrier (BBB) opening. Neurotoxicol 30, 636-646.

Cruz-Höfling, M.A., Tavares, J.C., Rapôso, C., 2015. Phoneutria nigriventer venom. In: Gopalakrishnakone, P., Corzo, G.A., Diego-Garcia, E., De Lima, M.E. (Eds.), Action in the Central Nervous System, Spider Venoms, Handbook of Toxinology. Springer Science, Singapore, pp. 1-23. http://dx.doi.org/10.1007/978-94-007 6646-4 1-1.

De Lima, M.E., Figueiredo, S.G., Matavel, A., Nunes, K.P., Silva, C.N., Almeida, F.M., Diniz, M.R.V., Cordeiro, M.N., Stankiewicz, M., Beirão, O.S., 2015. Phoneutria nigriventer venom and toxins: a review. In: Gopalakrishnakone, P., Corzo, G.A., Diego-Garcia, E., De Lima, M.E. (Eds.), Spider Venoms, Handbook of Toxinology. Springer Science, Singapore, pp. 1-24. http://dx.doi.org/10.1007/978-94-0076646-4_6-1.

Escoubas, P., Diochot, S., Corzo, G., 2000. Structure and pharmacology of spider venom neurotoxins. Biochimie 82, 893-907.

Filep, J.G., Delalandre, A., Beauchamp, M., 1997. Dual role for nitric oxide in the regulation of plasma volume and albumin escape during endotoxin shock in conscious rats. Circ. Res. 81, 840-847.

Finkbeiner, S.M., 1993. Glial calcium. Glia 9, 83-104.

Forshammar, J., Block, L., Lundborg, C., Biber, B., Hansson, E., 2011. Naloxone and ouabain ultralow concentrations restore $\mathrm{Na}^{+} / \mathrm{K}^{+}$-ATPase and cytoskeleton in lipopolysaccharide-treated astrocytes. J. Biol. Chem. 286, 31586-31597.

Gao, K., Wang, C.R., Jiang, F., Wong, A.Y., Su, N., Jiang, J.H., Chai, R.C., Vatcher, G., Teng, J., Chen, J., Jiang, Y.W., Yu, A.C., 2013. Traumatic scratch injury in astrocytes triggers calcium influx to activate the JNK/c-Jun/AP-1 pathway and switch on GFAP expression. Glia 61, 2063-2077.

Gewehr, C., Oliveira, S.M., Rossato, M.F., Trevisan, G., Dalmolin, G.D., Rigo, F.K., de Castro Júnior, C.J., Cordeiro, M.N., Ferreira, J., Gomez, M.V., 2013. Mechanisms involved in the nociception triggered by the venom of the armed spider Phoneutria nigriventer. PLoS Negl. Trop. Dis. 7, e2198.

Gomez, M.V., Kalapothakis, E., Guatimosim, C., Prado, M.A., 2002. Phoneutria nigriventer venom: a cocktail of toxins that affect ion channels. Cell Mol. Neurobiol. 22, 579-588.

Grishin, E., 1999. Polypeptide neurotoxins from spider venoms. Eur. J. Biochem. 264 $276-280$.

Habermann, E., 1989. Palytoxin acts through Na+, K+-ATPase. Toxicon 27, $1171-1187$.

Harold, D.E., Walz, W., 1992. Metabolic inhibition and electrical properties of type1-like cortical astrocytes. Neurosci 47, 203-211.

Kielian, T., 2006. Toll-like receptors in central nervous system glial inflammation and homeostasis. J. Neurosci. Res. 83, 711-730.

Le Sueur, L.P. Collares-Buzato, C.B., Cruz-Höfling M.A. 2004. Mechanisms involved in the blood-brain barrier increased permeability induced by Phoneutria nigriventer spider venom in rats. Brain Res. 1027, 38-47.

Le Sueur, L., Collares-Buzato, C.B., Kalapothakis, E., Cruz-Höfling, M.A., 2005. In vitro effect of the Phoneutria nigriventer spider venom on cell viability, paracellular barrier function and transcellular transport in cultured cell lines. Toxicon 46, 130-141.
Le Sueur, L., Kalapothakis, E., Cruz-Höfling, M.A., 2003. Breakdown of the bloodbrain barrier and neuropathological changes induced by Phoneutria nigriventer spider venom. Acta Neuropathol. 105, 125-134.

Lo, F., Kaufman, S., 2001. Effect of 5- $\alpha$-pregnan-3 $\alpha$-ol-20-one on nitric oxide biosynthesis and plasma volume in rats. Am. J. Physiol. 280, R1902-R1905.

Lencesova, L., O'Neill, A., Resneck, W.G., Bloch, R.J., Blaustein, M.P., 2004. Plasma membrane-cytoskeleton-endoplasmic reticulum complexes in neurons and astrocytes. J. Biol. Chem. 279, 2885-2893.

Linardi, A., Rocha e Silva, T.A., Miyabara, E.H., Franco-Penteado, C.F., Carodoso, K.C., Boer, P.A., Moriscot, A.S., Gontijo, J.A., Joazeiro, P.P., Collares-Buzato, C.B., Hyslop, S., 2011. Histological and functional renal alterations caused by Bothrops alternates snake venom: expression and activity of $\mathrm{Na}^{+} / \mathrm{K}^{+}$-ATPase. Biochim. Biophys. Acta 1810, 895-906.

Liu, X.L., Miyakawa, A., Aperia, A., Krieger, P., 2007. Na,K-ATPase generates calcium oscillations in hippocampal astrocytes. Neuroreport 18, 597-600.

Lowry, O.H., Rosebrough, N.H., Farr, A.L., Randall, R.J., 1951. Protein measurement with the Folin phenol reagent. J. Biol. Chem. 193, 265-275.

Miyakawa-Naito, A., Uhlén, P., Lal, M., Aizman, O., Mikoshiba, K., Brismar, H., Zelenin, S., Aperia, A., 2003. Cell signaling microdomain with Na,K-ATPase and inositol 1,4,5-triphosphate receptor generates calcium oscillations. J. Biol. Chem. 278, 50355-50361.

Moerman, L., Verdonck, F., Willems, J., Tytgat, J., Bosteels, S., 2003. Antimicrobial peptides from scorpion venom induce $\mathrm{Ca}(2+)$ signaling in HL-60 cells. Biochem. Biophys. Res. Commun. 311, 90-97.

Mohler, P.J., Davis, J.Q., Bennett, V., 2005. Ankyrin-B coordinates the Na/K ATPase, $\mathrm{Na} / \mathrm{Ca}$ Exchanger, and InsP3 receptor in a cardiac T-tubule/SR microdomain. PLoS Biol. 3, e423.

Molitoris, B.A., 1991. Inschemia-induced loss of epithelial polarity: potential role of the actin cytoskeleton. Am. J. Physiol. 260, F769-F778.

Paludo, K.S., Gremski, L.H., Veiga, S.S., Chaim, O.M., Gremski, W., Freitas Buchi, D., Nader, H.B., Dietrich, C.P., Franco, C.R., 2006. The effect of brown spider venom on endothelial cell morphology and adhesive structures. Toxicon 47, 844-853.

Persson, A.I., Thorlin, T., Eriksson, P.S., 2005. Comparison of immunoblotted delta opioid receptor proteins expressed in the adult rat brain and their regulation by growth hormone. Neurosci. Res. 52, 1-9.

Petricevich, V.L., Reynaud, E., Cruz, A.H., Possani, L.D., 2008. Macrophage activation, phagocytosis and intracellular calcium oscillation induced by scorpion toxins from Tityus serrulatus. Clin. Exp. Immunol. 154, 415-423.

Rapôso, C., Odorissi, P.A., Oliveira, A.L., Aoyama, H., Ferreira, C.V., Verinaud, L., Fontana, K., Ruela-de-Sousa, R.R., Cruz-Höfling, M.A., 2012. Effect of Phoneutria nigriventer venom on the expression of junctional protein and P-gp efflux pump function in the blood-brain barrier. Neurochem. Res. 37, 1967-1981.

Rapôso, C., Odorissi, P.A., Savioli, S.F., Hell, R.C., Simões, G.F., Ruela-de-Sousa, R.R., Oliveira, A.L., Cruz-Höfling, M.A., 2014. Triggering of protection mechanism against Phoneutria nigriventer spider venom in the brain. PLoS One 9, e107292.

Rapôso, C., Zago, G.M., Silva, G.H., Cruz-Höfling, M.A., 2007. Acute blood-brain barrier permeabilization in rats after systemic Phoneutria nigriventer venom. Brain Res. 1149, 18-29.

Rash, L.D., Hodgson, W.C., 2002. Pharmacology and biochemistry of spider venoms. Toxicon 40, 225-254.

Reis, H.J., Gomez, M.V., Kalapothakis, E., Diniz, C.R., Cordeiro, M.N., Prado, M.A., Romano-Silva, M.A., 2000. Inhibition of glutamate uptake by Tx3-4 is dependent on the redox state of cysteine residues. Neuroreport 11, 2191-2194.

Rodríguez-Moreno, A., Sistiaga, A., Lerma, J., Sánchez-Prieto, J., 1998. Switch from facilitation to inhibition of excitatory synaptic transmission by group I mGluR desensitization. Neuron 21, 1477-1486.

Sáez, J.C., Conteras, J.E., Bukauskas, F.F., Retamal, M.A., Bennet, M.V., 2003. Gap Junction hemichannels in astrocytes of the CNS. Acta Physiol. Scand. 179, 9-22.

Santello, M., Cali, C., Bezzi, P., 2012. Gliotransmission and the tripartite synapse. Adv. Exp. Med. Biol. 970, 307-331.

Schwaller, B., 2012. The use of transgenic mouse models to reveal the functions of $\mathrm{Ca}^{2+}$ buffer proteins in excitable cells. Biochim. Biophys. Acta 1820,1294-1303.

Sharma, G., Vijayaraghavan, S., 2001. Nicotinic cholinergic signaling in hippocampal astrocytes involves calcium-induced calcium release from intracellular stores. Proc. Natl. Acad. Sci. U. S. A. 98, 4148-4153.

Stávale, L.M., Soares, E.S., Mendonça, M.C., Irazusta, S.P., Cruz-Höfling, M.A., 2013. Temporal relationship between aquaporin-4 and glial fibrillary acidic protein in cerebellum of neonate and adult rats administered a BBB disrupting spider venom. Toxicon 66, 37-46.

Tiras, N.R., Udal'tsov, S.N., Mikheeva, I.B., Pakhotin, P.I., Moshkov, D.A., 2004. Morphofunctional changes in incubated Mauthner neurons in goldfish treated with peptides from scorpion venom. Neurosci. Behav. Physiol. 34, 687-692. 